\title{
The Tea 'Party' as a Conservative Social Movement
}

\author{
Zachary Courser
}

Published online: 29 November 2011

(C) Springer Science+Business Media, LLC 2011

What little recent academic analyses the Tea Party has received thus far has attempted to place it within the context of past scholarly work on conservative social movements. The comparison is not flattering, as social movements that originate from the right have almost invariably been portrayed as intolerant, resentful, ignorant, and paranoid (Bell 1963; Lipset 1955; Hofstadter 1955, 1965). For example, Tea Party opposition to the policies of the Obama administration is seen as a product of fear and racism in a recent article. The authors contend that "racial resentment stokes Tea Party fears about generational societal change, and fuels the Tea Party's strong opposition to President Obama." While these racists sentiments are not "conscious, deliberate, and publicly expressed," the authors insist they are part of a "nebulous fear" that informs the Tea Party movement. They go on further to characterize Tea Party rallies as reflecting Richard Hofstadter's "paranoid style of American politics" in their displays of irrational fear and extreme views. ${ }^{2}$ Researcher Chip Berlet ascribes to the Tea Party movement a variety of anxieties stemming from fears about the economy and "dark skinned immigrants, Muslim terrorists, gay marriage, abortion, and a liberal Black man in the White House." ${ }^{3}$ The term "populist" has been repeatedly applied to the Tea Party

\footnotetext{
${ }^{1}$ Vanessa Williamson, Theda Skocpol, and John Coggin, "The Tea Party and the Remaking of Republican Conservatism," Perspectives on Politics, March 2011: 34.

${ }^{2}$ Ibid., 35.

${ }^{3}$ Chip Berlet, “Taking Tea Parties Seriously: Corporate Globalization, Populism, and Resentment," Perspectives on Global Development \& Technology, Vol. 10 Issue 1, 2011: 12.
}

Z. Courser $(\bowtie)$

506 Avenue du 8 Mai 1945,

69300 Caluire et Cuire, France

e-mail: zcourser@gmail.com movement, which brings additional negative connotations of intemperance and hostility. However tempting it may be to lump the Tea Party together with characterizations of earlier social movements of the "radical right," a careful and objective comparison evinces few similarities. Moreover, the comparison with previous populist movements hides more than it reveals about the political nature of the Tea Party and the current state of American politics.

The fact that the vast majority of Tea Party supporters identify as conservative has invited comparison with earlier radical social movements of the right. An April 2010 poll found $73 \%$ of Tea Party supporters identified themselves as conservative. ${ }^{4}$ However, beyond the fact the movement is concentrated within the Republican Party and consists primarily of conservatives, it is not as Berlet attests "the type of right-wing populist movement seen previously throughout US history." 5 He states social movements on the right "often develop into a dualistic xenophobic force that demonize and scapegoat target groups. The outcome is aggression, discrimination, and violence." $" \mathrm{He}$ further contends the agenda of the Tea Party is a mix of "racial fears, economic anxieties, and gender panics" that challenge progressive values of equality and fairness. ${ }^{7}$ This characterization does not bear up under scrutiny and falsely places the Tea Party in the context of an academic tradition of marginalizing populist and conservative social movements as illiberal, intolerant, and radical. On the whole, Tea Party movement is neither racist nor radical, and its political demands fit within the mainstream of American politics. It is an inchoate demand for representation among

\footnotetext{
${ }^{4} \mathrm{CBS} /$ New York Times poll, April 5-12, 2010

${ }^{5}$ Berlet, 11.

${ }^{6}$ Ibid.

${ }^{7}$ Ibid. 14
} 
a significant portion of the American electorate that feels frustrated and marginalized by what is perceived as an unrepresentative political system. What makes the Tea Party movement distinctive is not its conservative character but rather the lack of political skill and organization amongst its adherents. Popular movements for inclusion in the political process are nothing new in America, but the Tea Party represents a departure in that its members are a loose confederation that seek no specifics, desires only protest, and seems to have rejected the idea of organization as a principle of enacting political change. These distinct features make the Tea Party something new in American politics: a protest movement without significant organization or leadership. It is a social movement for inclusion in the policy making process by citizens who have a deep aversion to government and lack significant knowledge of political organization.

\section{Legitimating Populist Democracy}

The idea that populist movements are energized primarily by irrational fears and anxieties that seek convenient scapegoats began during the 1950s in reaction to the anticommunist crusade of Senator Joseph McCarthy. Richard Hofstadter in his Age of Reform (1955) implied many parallels between the paranoia and extremism of McCarthyism and the Populists of the 1890s. ${ }^{8}$ Overall, his treatment of the Populists and their political fight is unsympathetic. He dismisses the hopes of the People's Party for political reform to be based in an "agrarian myth" and their fears and complaints regarding banks and railroads to be conspiratorial and paranoid. He refined and expanded the latter idea in his essay on the "paranoid style in American politics," wherein he traces a history of a paranoid tendency among social movements inspired by class, religious and ethnic conflicts. The impotence felt by marginalized or threatened groups that are caught within these conflicts and "cannot make themselves felt in the political process" generates unfounded beliefs and fantastic conspiracies among their members. ${ }^{9}$ Hofstadter offers a variety of examples of paranoid imaginings that members of various social movements have had through America history, ranging from fears over Freemasonry to the hysteria inspired by Senator McCarthy's crusade against communism.

Hofstadter, along with Daniel Bell, Seymour Martin Lipset, and others in the edited volume The Radical Right (1955, 1963), expanded the thesis regarding paranoid

\footnotetext{
${ }^{8}$ Margaret Canovan, Populism (New York: Harcourt Brace Jovanovich, 1981), 184.

${ }^{9}$ Richard Hofstadter, "The Paranoid Style in American Politics," in The Paranoid Style in American Politics and Other Essays (Chicago: University of Chicago Press, 1965), 39.
}

populists to include groups on the political right that were associated with anti-communism and McCarthyism. Borrowing from Theodore Adorno's Authoritarian Personality (1950), Hofstadter uses the term "pseudo-conservative" to describe the fringe groups on the right that displayed a deep distrust of mainstream politics, despised the New Deal and its supporters on the left, and held various conspiracy theories regarding communist subversion of American politics. He concludes that the fears and anxieties of the pseudo-conservatives resulted from the "rootlessness and heterogeneity of American life... of its peculiar scramble for status and its peculiar search for secure identity." lack of a stable social hierarchy and the mutability of social status in American life produced resentment and irrational fear in the radical right. Hofstadter notes that while past generations of Americans had been able to satisfy their desire to continually ascend "the American social edifice" aided by steady economic expansion, constant new settlement, and continual waves of immigration, opportunities for social advancement had narrowed in his time. ${ }^{11}$

Bell draws a direct comparison between the Populists of the 1890 s and the radical right of the 1950 s and 60 s as being "dispossessed" social groups that sought "targets on whom they can vent their resentments, targets whose power can serve to explain their dispossession." ${ }^{\prime 12}$ Bell emphasized the need of dislocated or threatened social groups to find a scapegoat to direct their anxieties. He also adopted Hofstadter's thesis that status anxiety fuels irrational political belief and radicalizes marginalized social groups, but goes further to claim that the radical right is bewildered by the complexities of contemporary politics and is unable to cope. The "politics of frustration" is at the core of radical right: "the sour impotence of those who find themselves unable to understand, let alone command, the complex mass society that is the polity today." 13 So for Bell it is not only status anxiety that inspires the radical right, but the fact that society and politics advanced beyond their understanding or perhaps even their capacity.

Bell's questioning of the capacity of the members of the radical right to conceive of their political world is indicative of a growing skepticism by academics in the 1950s and early 60s of democracy. Seymour Martin Lipset's Political Man (1960) characterized democracy as "something to be defended against the people" as most people lack the sophistication to accept the "norms of democracy."

\footnotetext{
${ }^{10}$ Richard Hofstadter, "The Pseudo-Conservative Revolt" in The Radical Right, Daniel Bell, ed. (New York: Criterion Books, 1963), 69.

${ }^{11}$ Ibid., 77.

${ }^{12}$ Daniel Bell, "The Dispossessed," in The Radical Right, Daniel Bell, ed. (New York: Criterion Books, 1963), 2-3.

${ }^{13}$ Ibid., 31.

${ }^{14}$ Canovan, 181.
} 
Behaviorists during this time also were drawing a dire picture of the capacities of average citizens. Notably, Philip Converse's work demonstrating the lack of consistent political attitudes and ideological constraint among the general public fueled a belief that only a small minority of political elites understood the issue cleavages of the major parties. ${ }^{15}$ These conclusions were leading many political scientists to question the capacity of the majority of citizens to meaningfully contribute to politics in a democracy.

Despite the focus on conservatism being a pathology of social movements, the above depiction of the "radical right" offers little evidence that conservatism is inherently illiberal or dangerous. It is likely that the authors, in drawing this conclusion, were influenced by the proximate effects of McCarthyism, combined with the influence of the study The Authoritarian Personality (1950) on scholarly understanding of the politics of the right. This seems to have led them to an indictment of conservative social movements as dangerous threats to democratic norms. In attempting to find psychological explanations for the extreme cruelty and atrocities of the Nazi regime in Europe, the authors of the Authoritarian Personality concluded that authoritarianism exists primarily as a function of personality in right-wing politics. ${ }^{16}$ According to the study, this personality trait makes people extremely susceptible to carrying out unconscionable acts if directed by an authority figure. Since this study, authoritarianism and its various illiberal extremes have been linked with conservatism and the politics of the right despite the historical evidence of leftist regimes and political groups that have exhibited similar authoritarian characteristics. Russia, North Korea, China, and other leftist governments, radical leftist groups such as the Weathermen or the Baader-Meinhof Group, in addition to contemporary environmental or animal rights extremists, all have exhibited authoritarianism. While it is incorrect to assume that anti-democratic impulses are wholly a phenomenon of the right, it is likewise wrong to assume that the same potential dangers do not lurk on the left.

The picture painted by the above authors of populist movements is bleak indeed. If accepted as an accurate depiction, it would suggest that the popular protest in American politics has largely been characterized by paranoia, irrationality, and fear. It would also suggest that these movements - if from the right-necessarily pose a danger to democratic norms. However, there is another side to populism on the right or the left that is a moderate and rational response to diminished opportunities to participate

\footnotetext{
$\overline{15}$ Philip Converse, "The Nature of Belief Systems in Mass Publics" in Ideology and Discontent, David E. Apter, ed. (Glencoe, IL: Free Press of Glencoe, 1964).

${ }^{16}$ T.W Adorno, E. Frenkel-Brunswik, D.J. Levinson, \& R.N. Sanford, The Authoritarian Personality (New York: Harper, 1950).
}

in the politics and policy making process. Populists movements by their vary nature attract political novices and fringe elements. However untidy populist movements appear at the margins, there are legitimate claims for representation behind them. Many past interpretations of populism and conservative social movements are elitist in their aversion to political conflict outside the narrow debates that occur between the two major parties, their reflexive condemnation of conservatism as authoritarian, and in their low estimation of the political wisdom of the average person. Reconsidering past populist movements in light of the thesis that they are motivated by legitimate frustrations over limited representation and access to the political process casts a more reassuring light on their nature.

It is necessary to define the kind of populism that is a moderate, legitimate demand for inclusion and distinguish from more radical forms of political protest. Margaret Canovan in her work on populism distinguishes between several types. They range from agrarian types such as farmers' radicalism or peasant revolts, to political dictatorships like Juan Peron's, or the reactionary populism of George Wallace. ${ }^{17}$ Her term "populist democracy" refers to movements that arise out of frustration by groups that feel unrepresented in the political process in a democracy. Populist democracy "aims at the closest possible approach to direct popular self-government without the intervention of a political elite" through the advent to direct democracy. She writes,

the ideals and devices of populist democracy arise precisely in political contexts where "democracy" in some sense is officially accepted as a norm, but where dissidents feel that democratic practice does not live up to the promise of the name. ${ }^{18}$

Canovan's definition refers most directly to the People's Party and the subsequent pursuit during the Progressive era of the referendum, direct primary, recall, and various other devices of direct democracy. A more generalizable and useful term for the study of American social movements is democratic populism, as it better connotes popular political energies constrained and organized within democratic norms. Social movements can be considered democratic populism when they display three primary traits:

1. a belief by members in the centrality of consent as the basis for legitimate government;

2. a perception that their representation in the political process has been or is in danger of being diminished or subverted;

\footnotetext{
$\overline{{ }^{17} \text { Canovan, } 13}$

${ }^{18}$ Ibid., 173-174.
} 
3. and a reliance on democratic mobilization to restore legitimacy to representation.

Elements of democratic populism have existed throughout American history. The Anti-Federalists' skepticism about the distance federalism would place between citizens and government contains elements of democratic populism. Thomas Jefferson's preoccupation with preserving states rights, championing the common man, and his founding of the first political party all contained elements of democratic populism. Jacksonian democracy in particular turned on notions of inclusion and equality among common men in the political process, the primacy of popular sovereignty to political legitimacy, and the conviction that participation in American politics ought not to be limited to a privileged few. ${ }^{19}$

The general movement for more democracy during the 1820 s had paved the way for the Jacksonians. In the election of 1820 , only 15 of 24 states used a popular vote to select electors for President, with many states posing significant barriers to the franchise such as property requirements. By 1828, only Delaware and South Carolina still did not hold a popular election for President. The restrictive franchises of many states liberalized a great deal in only 8 years: slightly over 100,000 voters participated in the election of 1820 , while over a million more citizens voted for president in 1828. The election of Jackson as president and the establishment of Democratic Party rule helped to further reinforce democratic populism as distinctive feature of American politics. Through the advent of party organization and patronage, the Jackson Democrats strengthened the control of citizens over government.

A democratic populist social movement that paralleled the Jacksonians was the Anti-Mason Party, which first developed during the late 1820s. The party grew out of an incident in 1826 where a former Freemason in New York State disappearedand was presumably murdered - after threatening to reveal the secrets of the order in a book. ${ }^{20} \mathrm{~A}$ firestorm of public fear over the secretive order's violent, potentially blasphemous conduct erupted starting in New York, but soon spread into nearby states. Richard Hofstadter includes the Anti-Masons as an example of the paranoid style of American politics. He dwells on the sometimes fantastic conspiracy theories and irrational fears that helped the movement to spread initially to include Anti-Masons among movements of the paranoid style. What he neglects is how the Anti-Masons very quickly transcended superstition to become a popular and well-organized party united against entrenched privilege.

Although Anti-Masons opposed Jackson as he was a Freemason, they shared his commitment to expanding opportunities for average citizens to participate in politics. They saw

\footnotetext{
${ }^{19}$ Marvin Meyers, The Jacksonian Persuasion (New York: Vintage, 1957), 31

${ }^{20}$ Hofstadter, The Paranoid Style in American Politics, 17.
}

Freemasonry chiefly as an organization that subverted political equality: "a fraternity of the privileged classes, closing business opportunities and nearly monopolizing political offices." ${ }^{21}$ The party quickly outgrew its focus on Freemasons to become a general movement for the inclusion of common citizens in politics and a scourge of elites. The Anti-Masons were the first third party to elect representatives to the House in 1828 , and they pioneered the holding of party conventions to nominate presidential candidates in 1832 . The also managed to elect governors in Pennsylvania and Vermont before gradually losing their base of support to the Whig Party. The legacy of Anti-Mason Party was to spread democratic norms through their emphasis on inclusion of average Americans in politics. Despite their record of democratic achievement, Hofstadter insists "what must be emphasized here [about the Anti-Masons]... is the apocalyptic and absolutist framework in which this hostility to Masonry was usually expressed." 22 The paranoid rhetoric of a few AntiMasons observed by Hofstadter never manifested itself in a political program of majority tyranny, violence, or scapegoating. Rather, it organized a significant and underrepresented body of public opinion to better express itself democratically.

Another prominent populist democratic movement, the Populists of the 1890s, is often portrayed as irrational and paranoid by twentieth century historians and political scientists. But the Populists had well-founded reasons to battle against a political system that had ceased to represent the interests of middle-class farmers. According to Walter Nugent, in his study of Kansas Populism, writers on Populism, "most of them inheritors of Wilsonian idealism, practitioners of Turnerian historiography, and participants in the reform urge of the thirties," created a skewed profile of the Populist movement as an intolerant, unintelligent mass of "grimy overalls and shiny frock coats" bent on toppling economic elites. ${ }^{23}$ Hofstadter and his contemporaries contribute to this prejudice by emphasizing Populism's "dull gray petit bourgeois authoritarianism running roughshod over the rights of individuals and minorities."24

Nugent cites the narrow and selective sources Hofstadter uses to draw this conclusion, and in his own analysis finds a much more rational basis for the rise of Populism. ${ }^{25}$ While the agrarian economic distress of the Midwest in the 1890s was a proximate cause of the Populist to form as a party, and low income farmers formed its core, the movement was a more profound reaction than an intemperate agrarian revolt against moneyed interests would

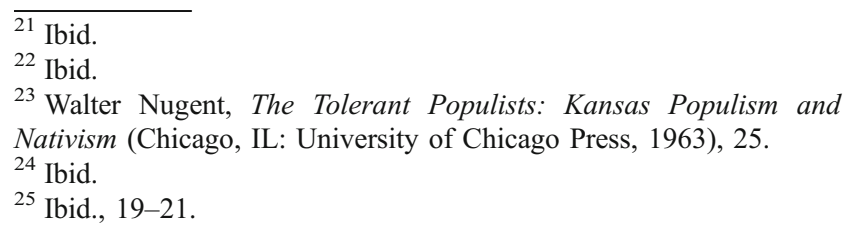


explain. Populists as a whole were not impoverished farmers, eager for radical reform fueled by class hatred. The Populists were not "living in some neurotic agrarian dream world" but rather they were

as a group hardly distinguishable from their Republican neighbors, except for a probably higher mortgage indebtedness, and their greater degree of political and economic awareness. The great majority could be called "middle-class," and they were interested in preserving what they considered to be their middle-class American ideals and substance. ${ }^{26}$

They were bound by "common indebtedness, common price squeezes, common democratic and human ideals, and common wrath at the infringement of them., 27

Defending agrarian interests was a large part of the equation, but at the heart of the Populist movement was a loss of confidence in political parties and legislatures to represent their interests. In states where political parties were responding to calls for agrarian reform such as regulating railroad shipping rates, the Populist movement gained little ground. While Populists achieved great electoral success in Kansas, Nebraska and the Dakotas, they were virtually ignored in Iowa which was under economic distress just as severe. ${ }^{28}$ Kansas and Nebraska were one-party states, with the Republican Party holding such an unchallenged control over each state's politics that elections were largely uncompetitive. ${ }^{29}$ Iowa, by contrast, enjoyed healthy competition between the Democrats and Republicans, with each anxious to exploit any issues that might prove popular among the electorate. As a consequence, the party system and legislature were more responsive to the complaints of Iowa farmers, and agrarian interests organized into non-partisan interest advocacy groups. Meaningful reform of railroad rates and an atmosphere of cooperation resulted in Iowa politics.

In Kansas and Nebraska, the Republican Party was much more concerned with the views of railroads and bankers, believing that reform favoring farm interests was economic folly. The inability of avowedly Republican farmers to interest their representatives in their economic plight led many to conclude the system itself was corrupt and to seek alternative means of influencing the political process. During the 1880s and 90s the response of farm interests was a third party alternative, the People's Party. In states like Kansas and Nebraska, a breakdown of the representation of the interests of farmers by their own party fueled

\footnotetext{
${ }^{26}$ Ibid., 242.

${ }^{27}$ Ibid.

${ }^{28}$ Jeffrey Ostler, "Why the Populist Party Was Strong in Kansas and Nebraska but Weak in Iowa," The Western Historical Quarterly, vol. 23, no. 4 (Nov. 1992): 452, 460.

${ }^{29}$ Ibid., 453.
}

skepticism of republican institutions. While frustration and political impotence drove People's Party supporters to seek alternatives to representative government, they sought redress in democratic forms and helped to mobilize a significant minority to voice their concerns.

To conclude the discussion of democratic populism, movements like the Anti-Masons and the People's Party were motivated by legitimate concerns over their diminished representation in the political process. Both movements mobilized citizens and managed to enact significant political reforms. Most importantly, instead of engaging in the politics of resentment and paranoia as has been traditionally asserted, they sought redress in democratic forms of protest by organizing their supporters and participating in the electoral process. There is no doubt there were unrefined elements in each movement that indulged in conspiracy theories informed by wanton ignorance. However, the paranoid few that stood at the margins were a reflection of the demotic nature of populist movements, not proof of some kind of incipient illiberal impulse of the dispossessed.

\section{The Tea Party as a Social Movement for Populist Democracy}

The Tea Party movement fits imperfectly into the category of populist democracy. Tea Partiers are energized by a feeling that their ability to influence the policy process is limited and the legitimacy of the political process is in question. The movement also seeks to redress this frustration of their political representation through protest, but not significantly through mobilization. This makes the Tea Party movement distinctive from earlier movements: its unwillingness to mobilize voters and its lack of organization. While past movements like the Anti-Masons and Populists chose the device of a political party to bring their concerns to bear on the political process, Tea Partiers have been more content to stand on the sidelines and have actively resisted organizing to elect candidates, or coalescing around a leader. The atomism of the movement is distinctive and troubling, as it is reflection of a diminished possibility of political activity outside established networks of interest groups and the current two major political parties in America.

While the Tea Party has focused its efforts within the Republican Party, they are not strong partisans. Tea Partiers are primarily conservative and overwhelmingly oppose Democratic Party candidates, but they are not enamored of the Republican Party either. In April of 2010, only 44\% of Tea Party supporters had a favorable opinion of the Republican Party, while only $5 \%$ of Tea Party supporters identified as Democrats, and $41 \%$ identified as independ-

\footnotetext{
${ }^{30}$ CBS News / New York Times poll, April 5-12, 2010
} 
ents. ${ }^{30}$ This independence, combined with skepticism of the Republican Party, was on display in a variety of Senate primaries in 2010, with Tea Party factions concentrating their political efforts on subverting Republican order by challenging party regulars. Mike Castle of Delaware, for example, had served as a congressman and governor, and was the state party's choice in the race for the Senate. Sue Lowden was the chair of the party in Nevada, and helped to leverage her connections and influence to secure the support of elected officials and party regulars in the state. In Alaska, Lisa Murkowski was a prime example of party regularity. Having first taken office thanks to her governor father appointing her to the seat he had just vacated in 2002, Murkowski was endorsed by virtually the entire party establishment for reelection. In Colorado, former lieutenant governor and longtime government administrator Jane Norton was endorsed by prominent Republicans like John McCain, Rick Santorum, Orrin Hatch, and Arizona governor Jane Brewer in her race for the Senate. All four candidates lost their primaries thanks in large part to energized Tea Party voters seeking to break ranks with the Republican establishment.

Pollster Scott Rasmussen suggests the source of the Tea Party's distrust of both parties and their independent conviction derives from a belief that the representative institutions of American politics have ceased to represent their interests. The dismal approval numbers Tea Partiers report about Congress, the president, and both political parties point to a profound alienation from the established political order. Based on surveys of Tea Partiers, Rasmussen concludes that "the real issue driving the [Tea Party] movement is not partisan rage on the right but a profound crisis of governmental legitimacy that should deeply concern us all." ${ }^{\text {31 }}$ Rasmussen believes the core of the conflict between the Tea Party movement and political institutions derives from a divide between an elite "political class" and the political "mainstream." Using what he calls a Political Class Index - formed from the answers to three survey questions regarding trust in government-he divides Americans first into a "mainstream" that distrusts political leaders, believes the government has become a special interest, and that business colludes with government at the expense of consumers and workers. ${ }^{32}$ The "political class" sees the opposite as being the case, and makes up $7 \%$ of the electorate, compared to $55 \%$ for the mainstream. The divide between elites and the mainstream cuts across partisan lines, as an equal number of Republicans and Democrats score as mainstream. ${ }^{33}$ Rasmussen Reports polling during 2009 and 2010 (see Table 1) shows a significant divide between the

\footnotetext{
${ }^{31}$ Scott Rasmussen \& Douglas Schoen, Mad as Hell: How the Tea Party Movement is Fundamentally Remaking Our Two-Party System (New York: Harper, 2010), 15.

${ }^{32}$ Ibid., 85.

${ }^{33}$ Ibid., 86 .
}

Table 1 The divide between elite and mainstream opinion

\begin{tabular}{lll}
\hline & Agree & \\
Statement $^{\mathrm{a}}$ & Political Class & Mainstream \\
$\begin{array}{l}\text { The federal government has } \\
\text { the consent of the governed. }\end{array}$ & $77 \%$ & $6 \%$ \\
$\begin{array}{l}\text { The nation heading in the right } \\
\text { direction. }\end{array}$ & $86 \%$ & $19 \%$ \\
$\begin{array}{l}\text { Voter approval should NOT be } \\
\text { required for all tax increases. }\end{array}$ & $74 \%$ & $15 \%$ \\
$\begin{array}{l}\text { The financial industry bailouts } \\
\text { were a good idea. }\end{array}$ & $61 \%$ & $26 \%$ \\
$\begin{array}{l}\text { Question } \\
\text { Do you have a favorable view } \\
\text { of the Tea Party? }\end{array}$ & Yes & \\
Are you a Tea Party member? & $2 \%$ & Mainstream \\
\hline
\end{tabular}

${ }^{\text {a }}$ Rasmussen Reports, April 21, 2009; July 12-13, 2010

${ }^{\mathrm{b}}$ Rasmussen Reports, October 6-7, 2010

political class and the mainstream on questions about and public policy and the legitimacy of American government.

There is not a perfect fit between the political mainstream and Tea Party supporters, but it is clear the Tea Party fits firmly within the mainstream. A majority of the mainstream supports the Tea Party and about one-quarter identify as members, while vanishingly few of the political class do (see Table 1). According to an extensive survey of Tea Party attitudes taken in April of 2010, opinion is as polarized in the movement or more so than Rasmussen's mainstream on issues of governance and legitimacy. Only $6 \%$ feel the country is going in the right direction, $73 \%$ feel the President does not understand their problems, and virtually none approve of the job Congress is doing (see Table 2). Even more telling is that among Tea Party supporters that were angry with the federal government, the top two reasons why had to do with healthcare legislation and that Washington was "not representing the people."

That healthcare should be the number one cause of anger likely derives from the spontaneous protests that erupted in August of 2009 over the Democratic Congress's reform bill. The sometimes extreme anger and scorching criticism that congresspersons experienced that summer-during what is usually a sleeping series of town hall meetings in their districts - shocked the media and party leaders. Speaker Nancy Pelosi dismissed the reaction as "astroturfing," implying it was orchestrated by interest groups to look like genuine grassroots protest. In an opinion editorial co-written by Majority Leader Steny Hoyer, she called the angry outbursts "an ugly campaign... to disrupt public meetings and prevent members of Congress and constituents from conducting a civil dialogue. ${ }^{34}$ In hindsight, this claim is difficult to substantiate.

\footnotetext{
$\overline{{ }^{34} \text { USA Today, }}$ August 10, 2009.
} 
Table 2 Tea Party views on the political order

\begin{tabular}{lcc}
\hline Question & Tea Party & All respondents \\
\hline $\begin{array}{l}\text { Agree that the nation heading in the } \\
\text { right direction. }\end{array}$ & $6 \%$ & $59 \%$ \\
Feeling toward the federal government is... & \\
Dissatisfied/Angry & $94 \%$ & $67 \%$ \\
If angry, what are you most angry with the federal government about? \\
Health care reform & $16 \%$ & N/A \\
Not representing the people & 14 & \\
Government spending & 11 & \\
Unemployment/Economy & 8 & \\
Size of government & 6 & 22 \\
Other & $22 \%$ & $58 \%$ \\
Do you think President Obama understands your needs and problems? \\
Yes & $24 \%$ \\
No & 73 & 39 \\
Do you approve of how Congress is handling its job? \\
Yes & $1 \%$ & $17 \%$ \\
No & 96 & 96 \\
\hline
\end{tabular}

CBS / New York Times poll, April 5-12, 2010

The election of Republican Scott Brown in Massachusetts in January 2010, and the disastrous election results in November of that year for vulnerable Democratic House members that voted for healthcare reform indicates the protests were genuine. The flatfooted and muted reaction of elected officials to the protests also strongly suggests that a chasm between elites and the general public does exist.

It is not only academics that have suggested the Tea Party movement is radical and presents a danger to democratic norms. The media helped to characterize the Tea Party as a dangerous fringe movement beginning in the summer of 2009. According to the conservative Media Research Center (MRC), 44\% of network news stories about the Tea Party through April 2010 suggested "that the movement reflected a fringe or extremist nature." ${ }^{35}$ Moreover, network TV news was late in covering the movement, beginning to give significant coverage only as Scott Brown's Senate campaign became competitive in January 2010. The MRC concluded in their report that the

negative treatment of the Tea Party is a glaring example of a media double standard. Rather than objectively document the rise and impact of this important grassroots movement, the "news" networks

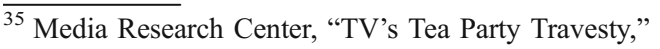
$<$ http://www.mrc.org/specialreports/uploads/teaPartytravesty.pdf>, accessed April 20, 2011.
}

instead chose to first ignore, and then deplore, the citizen army mobilizing against the unpopular policies of a liberal President and Congress. ${ }^{36}$

The intense conservative views of the Tea Party, the claims of media bias by a conservative media group, and the aloof dismissal by Democratic congressional leaders of grassroots protest all point to a divide between elites and average citizens, and a polarized political atmosphere. Could it the Tea Party movement be a sign of a "culture war" raging in American politics? Morris Fiorina describes culture war as "a displacement of the classic economic conflicts that animated twentieth-century politics in the advanced democracies by newly emergent moral and religious ones." ${ }^{\text {37 }}$ While it is tempting to view the Tea Party in this context, the evidence does not bear out the conclusion that the movement is part of a culture war. While the Tea Party movement is made up primarily of conservatives, the focus of its membership is on increasing their representation in the political process and restraining the reach of the federal government. Moral and religious issues do not even show up as secondary concerns. For example, in April 2010 only 14\% of self-identified Tea Party members responded that social issues were more important that economic issues. In another survey conducted at the University of Washington in March 2010, 69\% of Tea Party supporters thought homosexuals should be allowed to serve in the armed forced, and $62 \%$ supported laws to protect homosexuals from job discrimination. ${ }^{38}$ These are hardly hallmarks of a conservative social movement waging a culture war focused on religious and moral issues.

The same survey measuring attitudes about homosexuality has also been cited as proof that higher levels of racist attitudes exist among Tea Party supporters. ${ }^{39}$ According to researchers at the University of Washington, Tea Party "true believers" responded significantly higher than all whites surveyed to questions that are supposed to indicate racist attitudes toward African Americans. To a question about whether "blacks" should overcoming prejudice without "special favors," $88 \%$ of Tea Party "true believers" agreed, compared to $70 \%$ of all whites surveyed. Another question asking whether "over the past few years blacks have gotten less than they deserve," $83 \%$ of Tea Partiers disagreed, compared to $72 \%$ of all whites surveyed. If these questions are true indicators of racism, the conclusion to draw is that a significant majority of all whites are racist, and Tea Partiers just a fraction more. But it is critical to note that

\footnotetext{
${ }^{36}$ Ibid.

${ }^{37}$ Morris Fiorina, The Culture War? The Myth of a Polarized America, $2^{\text {nd }}$ ed. (New York: Longman, 2006), 2.

${ }^{38}$ University of Washington Multi-state Survey of Race \& Politics, March 2010. <http://depts.washington.edu/uwiser/mssrp_table.pdf>, accessed May 1, 2011.

${ }^{39}$ Williamson, Skocpol, and Coggin, 34; Berlet, 12.
} 
this was not a national but a multi-state survey that selectively polled presidential election "battleground" states: California, Georgia, Michigan, Missouri, Nevada, North Carolina, and Ohio. Given three of these states are former members of the Confederacy, there appears to be a strong selection bias that could affect the accuracy of questions about racial attitudes. The suggestion of bias is reinforced by observations of Tea Party members in Massachusetts that overall demonstrated a "vigilance... against explicit racism" and an active policing of their ranks to exclude avowed racists. ${ }^{40}$

While $39 \%$ of Tea Party members identified as evangelical Christians, social issues still did not predominate among them: only $35 \%$ said social issues were more important than economic issues. Religiosity was actually negatively correlated with turnout for Senate Tea Party candidates in both the Colorado Republican primary and the Utah Republican convention. ${ }^{41}$ There have been attempts by evangelicals to capitalize on Tea Party unrest to advance a political agenda focused on religious and moral issues, but there is no evidence to suggest it has affected the course of the movement. Joseph Farah, an evangelical and founder of the conservative news aggregator World Net Daily, wrote a book entitled The Tea Party Manifeso: A Vision for American Rebirth. Farah attempts to define the purpose of the Tea Party as taking "America back from the precipice - to revive liberty, restore social justice, and jump-start a moral renewal." ${ }^{, 42}$ He states the Tea Party is faced with a "spiritual battle" to restore the American Dream that is to be "fought in the spiritual realm, with prayer and obedience to God. ${ }^{, 43}$ Despite these pleas for Tea Partiers to not "eschew 'social issues," the Tea Party members have not been moved to make them a focus. $^{44}$

The Tea Party is not exempt from criticism for holding conspiratorial ideas based not in fact but on unfounded suspicion. Many Tea Party members and groups have nurtured the idea that President Barack Obama was not born in the United States, and have repeatedly rejected convincing evidence to contrary. However, the "birther" belief is not integral to Tea Party's political outlook, and runs throughout conservative opinion among activists who distrust the president. For example, a February 2011 poll

\footnotetext{
${ }^{40}$ Williamson, Skocpol, and Coggin, 34.

${ }^{41}$ Christopher F. Karpowitz, J. Quin Monson, Kelly D. Patterson, Jeremy C. Pope, "Tea Time in America? The Impact of the Tea Party Movement on the 2010 Midterm Elections," PS: Political Science \& Politics, April 2011: 307.

42 Joseph Farah, The Tea Party Manifesto: A Vision for an American Rebirth (Washington, DC: WND Books, 2010), 23

${ }^{43}$ Ibid., 24

${ }^{44}$ Ibid., 41
}

found that $51 \%$ of Republican primary voters doubted Obama was born in the United States. ${ }^{45}$ However, as a new book argues, unsettling suspicion exists on both sides of the partisan divide. ${ }^{46}$ The "truther" movement, which developed after the September 11 terrorist attacks, holds that President George W. Bush, Vice President Cheney, and the federal government conspired to plan the destruction of the World Trade Center towers. The "truther" movement has had a nearly equal hold on the imagination of Democrats: a 2007 poll found that $42 \%$ of Democratic voters believe that Bush or Cheney "either allowed the attacks to happen or deliberately caused the attacks to happen, presumably for political gain or to reap a financial windfall by waging way for oil in the Middle East. ${ }^{, 47}$ The distrust and paranoia of partisan elites exists on both sides of the mainstream, yet another sign that mainstream Americans feel their representation in the political process has been diminished or subverted.

\section{The Problems of Elite Domination and Democratic Anomie}

It is not a culture war that Tea Partiers are waging; it is one for populist democracy against an elite domination of politics. Rasmussen's survey research suggests that a significant divide exists between elites and average voters, which forms a primary cleavage in contemporary politics. Fiorina in his work on the culture war dispels the notion that a majority of Americans are politically polarized, but he does find that polarization exists primarily among elites. He suggests there is a mistaken impression that a majority of Americans are polarized because the face of American politics is dominated by an unrepresentative and aloof array of elites: "the collection of officeholders, party and issue activists, interest group leaders, and political infotainers who constitute the public face of politics in contemporary America." 48 This "political class" wages a culture war that does not reflect the mainstream attitudes of average Americans, and through their dominance in the media and government skews political discourse toward the priorities of the elite. Fiorina concludes that there is a "disconnect between the world of contemporary Americans and the political order that purports to represent them"

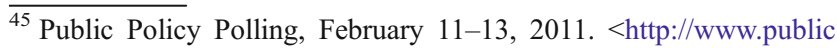
policypolling.com/pdf/PPP_Release_US 0215.pdf>, accessed May 8, 2011.

${ }^{46}$ Jonathan Kay, Among the Truthers (New York: Harper Collins, 2011).

${ }^{47}$ Jonathan Kay, "Beyond the Lunatic Fringe," Wall Street Journal, May 7-8, 2011.

${ }^{48}$ Fiorina, 16.
} 
that discourages average people from taking part in politics. ${ }^{49}$

Elite opinion is necessary for democratic politics to work. E.E. Schattschneider defined democracy as

a competitive political system in which competing leaders and organizations define the alternatives of public policy in such a way that the public can participate in the decision-making process. ${ }^{50}$

However, in order for elites to aide the public in making political decisions they must have a strong connection and sympathy with the concerns and experience of the general public. John Zaller identifies the necessity of elites working cooperatively with average voters in order for mass opinion to work in the public interest in democratic societies. Zaller sees politics as a kind of division of labor, where experts discuss, debate, and decide on policy positions on behalf of like-minded citizens who form the mass of public opinion in a democracy. Average citizens access this expert discourse and adopt the views of elites that share their own political predispositions. In order for this system to work, "predispositional differences among the experts" must parallel "those within the general public." Likewise, there must exist "a press that...provides ample coverage of all expert viewpoints, where the term 'expert' is broadly construed to include anyone having specialized knowledge of a problematic subject." ${ }^{, 51}$

In Zaller's model of mass opinion, if the operation of expert opinion no longer induces citizens to adopt opinions that they would otherwise form "if aware of the best available information and analysis," a state of elite domination would exist. ${ }^{52}$ If the operations of elite opinion no longer operated in tandem with the political predispositions of the general public, the outcome would be a gradual deadening of interest in politics among average people. The gradual exit of the public from politic activity would necessitate other, likely less democratic institutions to form to continue to perform essential political activities such as formulating policy and administrating government. ${ }^{53}$

The Tea Party movement operates within a political process that is dominated by entrenched interest groups that are not responsive to public opinion, and supporters of the movement know it. The frustration Tea Partiers felt over the federal bailout of Wall Street, the rescue of General Motors,

\footnotetext{
${ }^{49}$ Ibid., 204.

${ }^{50}$ E.E. Schattschneider, The Semisovereign People: A Realists View of Democracy in America (New York: Wadsworth, 1975), 138.

${ }^{51}$ John Zaller, The Nature and Origins of Mass Opinion (Cambridge, UK: Cambridge University Press, 1992), 314.

52 Ibid., 313

${ }^{53}$ This idea was first suggested in Arthur M. Schlesinger \& Erik M. Eriksson, "The Vanishing Voter," The New Republic, October 15, 1924.
}

or the convoluted manner the healthcare reform bill was passed into law, all reflect the responsiveness of government to the demands of interest groups. It also shows the lack of responsiveness of the political parties and the established political order to popular opinion. It is not only Tea Partiers that recognize the diminished capacity of parties to represent the mainstream of American. The dominance of interest groups over the policy process has existed for some time, but the recognition of its illegitimacy is dawning on an increasingly large segment of the electorate. A survey of independent voters before the 2010 midterm elections found that the top reason respondents identified as independent was they felt "both parties care more about special interests than average Americans." $5464 \%$ of independents cited this was a major reason they were not affiliated with either party.

The Tea Party movement is primarily a conservative one because of its aversion to government, and its distrust of the president and a Congress that was before 2011 uniformly controlled by the left. But that is not to say that elite domination is a problem that only affects the right: the problem is of critical importance to American democracy. Writers from the left have observed a growing distrust of by voters of the established political order, especially among the white middle-class. Kevin Phillips observed a trend toward "middle-class populism" in the early 1990s, fed by the conviction among "ordinary citizens" to "official Washington's apparent capture by special-interest groups. ${ }^{, 55}$ Ruy Teixeira and Joel Rogers also observe a loss of confidence by the middle-class in the federal government. All of these authors, however, also see declining prosperity among the middle-class - and the growing prosperity of the wealthiest Americans - as the primary cause of their discontent. Citing demographic data of downward shifts in the average wealth of the middle-class, Teixeira and Rogers make the case that there exists a "forgotten majority" of Americans that the federal government is no longer responding to. The key to their understanding of the dissatisfaction of white middle-class voters is that "the degree to which the benefits of growth and productivity are widely shared is a basic measure of economic performance in a democracy." ${ }^{56}$ Therefore, as the average wealth of middle-class voters began to stagnate beginning in the 1970s, and the wealth of the richest Americans rose, this economic inequality drove a growing middle-class discon-

\footnotetext{
${ }^{54}$ Pew Research Center for the People \& the Press, "Independents Oppose Party in Power... Again," September 23, 2010, 25.

${ }^{55}$ Kevin Phillips, Boiling Point: Republicans, Democrats, and the Decline of Middle-class Prosperity (New York: Random House, 1993), 80

${ }^{56}$ Ruy Teixeira and Joel Rogers, America's Forgotten Majority: Why the White Working Class Still Matters (New York: Basic Books, 2000), 11.
} 
tent. They nuance this view to say it is a combination of economics and values that feed middle-class discontent:

we believe that a disjuncture between economic experience and values has fundamentally shaped the political behavior of the forgotten majority. ...the values we have in mind are deeply held and broadly shared ones about opportunity, fair reward for effort, the centrality of hard work and individual achievement, and social commitment. ${ }^{57}$

This "values-experience disjuncture" leaves the middleclass feeling unrepresented in the political process and highly critical of government. Teixeira and Rogers identify this violation of middle-class values as a driving force among Perot voters in the early 1990s. ${ }^{58}$ It is likewise an influence on the Tea Party movement, but concerns over economic inequality or anxiety over economic dislocation does not appear to be a strong source of Tea Party discontent. While definitely a white, middle-class movement $(76 \%$ of Tea Partiers identify as middle or working class, and $89 \%$ are white), the Tea Party movement also primarily consists of conservatives and independents (73\% conservative, $41 \%$ independent). ${ }^{59}$ Teixeira and Rogers' suggestion that a more activist government that equalizes economic benefit is the solution to middle-class discontent is not a conclusion these conservatives would likely support. Moreover, Tea Party members were less concerned than average about losing their jobs and are slightly more satisfied about their financial situation: $58 \%$ were just as likely as average to be unconcerned about falling out of their current social class (see Table 3). The motivating force behind the Tea Party is not concern over economic inequalities, but a perception that their values are not being reflected in politics or the economy. For example, interviews with Boston area groups revealed that "underlying many specific Tea Party worries is distrust of politicians, the sense that the political class is not responding or accountable to "average Americans." ${ }^{60}$ This distrust was reflected in repeated references to the value of work and its relation to deservingness among Tea Party members. Obviously, the bailout of Wall Street helped feed the perception that work and individual effort were not being rewarded by the political system. Rather, the reckless economic risks of bankers and mortgage defaulters were being unfairly subsidized by taxpayers.

The feeling that the established political order has stopped responding to the concerns of average voters has led to a call for populist democracy by the Tea Party. But
Table 3 Economic views of the Tea Party

\begin{tabular}{lcc}
\hline Question & Tea Party & All respondents \\
\hline How would you rate your financial situation? & \\
Very good & $8 \%$ & $9 \%$ \\
Fairly good & 70 & 64 \\
Fairly bad & 16 & 16 \\
Very bad & 4 & 9 \\
Which best describes the way you and your family have been affected \\
by the recession? \\
Hardship & $14 \%$ & $19 \%$ \\
Difficult & 55 & 50 \\
Not much effect & 1 & 30 \\
Positive effect & & 1 \\
How concerned are you about you or someone in your household \\
losing your job in the next year? \\
Very concerned \\
Somewhat concerned & $30 \%$ & $36 \%$ \\
Not at all concerned & 25 & 26 \\
Do you ever feel as if you're at risk of falling out of your current \\
social class? \\
Yes \\
No & $41 \%$ & $39 \%$ \\
\hline
\end{tabular}

CBS News / New York Times Poll, April 5-12, 2010

their loss of confidence in the party system to respond to their demands has led them to a strange place organizationally. Tea Party groups have not displayed the organizational skill or drive of past movements for populist democracy. ${ }^{61}$ In the 2010 midterm election, a few organized, professional groups like FreedomWorks and the Tea Party Express (not to mention the Republican Party itself) did much of the groundwork attributed to the Tea Party movement. Putting aside the work of the Tea Party Express, candidates who associated themselves with the Tea Party movement worked within a traditional candidate-centered model of campaigning with minimal help from independent, grassroots Tea Party organizations. A canvass of over 600 Tea Party groups conducted in October, 2010 on the eve of the election reveals an independent, atomized, leaderless movement. Only 29\% of Tea Party groups reported campaigning for candidates during the election season, and those who did worked through individual candidates' organizations to assist get-out-the-vote drives. ${ }^{62}$ A plurality of groups chose not to affiliate with any national or state organization and identified "nobody" as the figure

\footnotetext{
${ }^{61}$ Zachary Courser (2010) "The Tea Party at the Election," The Forum: Vol. 8 : Iss. 4, Article 5.

${ }^{62}$ Washington Post Tea Party Canvass, October 6-13, 2010.
} 
that represented the Tea Party movement. The majority of the Tea Party groups canvassed thought the purpose of their group was to "operate as a network of independent political organizations," with only $4 \%$ stating it was to start a new political party.

While individual politicians are exploiting the name "Tea Party" for a variety of purposes, it seems that the movement itself has not developed into an effective organization for enacting political change. The third characteristic populist democratic movements - the reliance on mobilization to restore legitimate representation - is a criteria that the Tea Party fails to meet. The distrust of parties, interest groups, elites, and the established political order has limited the reach of the movement politically. The Tea Party exists in what I term a democratic anomie: an unstable political state of unrest and alienation that derives from a lack of organizational knowledge.

Past social movements for populist democracy have often found the establishment of a political party-or at least some mobilization of their members during elections - to be the primary means of restoring their voice in the political process. The Tea Party is distinctive in its resistance to organization. It has engaged in various protests, and led by a handful better organized factions, it had an impact on several primaries for the U.S. Senate. However, it has not risen to a level of organization necessary to exert deliberative influence on the policy process. While it clearly falls short of being a political party, it also falls short of being a fully formed social movement as it continues to be leaderless and resistant to mobilization. As noted by Tocqueville, "in democratic countries knowledge of how to combine is the mother of all other forms of knowledge; on its progress depends that of all others." ${ }^{, 63}$ Americans used to be quite good at organizing themselves to effect political change of all varieties, moving him to remark "I have often admired the extreme skill [Americans] show in proposing a common object for the exertions of very many and in inducing them voluntarily to pursue it." ${ }^{64}$ One doubts that Tocqueville would looks so approvingly on contemporary American politics, or the political skill displayed by the Tea Party movement. It is possible a long period of elite domination over American politics has atrophied these skills to such a level that future popular protest is likely to be a muted, frustrated, unorganized affair.

\footnotetext{
${ }^{63}$ Alexis de Tocqueville, Democracy in America, J.P. Mayer, ed. (New York: Perennial, 2000), 517

${ }^{64}$ Ibid., 514.
}

\section{Further Reading}

Adorno, T. W., Frenkel-Brunswik, E., Levinson, D. J., \& Sanford, R. N. 1950. The Authoritarian personality. New York: Harper.

Apter, D. E. 1964. Ideology and discontent. Glencoe: Free Press of Glencoe.

Bell, D. (Ed.). 1963. The radical right. New York: Criterion Books.

Berlet, C. 2011. Taking Tea Parties seriously: corporate globalization, populism, and resentment. Perspectives on Global Development \& Technology, 10(1).

Canovan, M. 1981. Populism. New York: Harcourt Brace Jovanovich.

Constain, A. N., \& McFarland, A. S. (Eds.). 1998. Social movements and American political institutions. Lanham: Rowman \& Littlefield.

Courser, Z. 2010. The Tea Party at the election. The Forum, 8(4), article 5 .

Dahl, R. A. 1961. Who governs? New Haven: Yale University Press.

Farah, J. 2010. The Tea Party manifesto: A vision for an American rebirth. Washington, DC: WND Books.

Fiorina, M. 2006. The culture war? The myth of a polarized America (2nd ed.). New York: Longman.

Hofstadter, R. 1965. The paranoid style in American politics and other essays. Chicago: University of Chicago Press.

Kay, J. 2011. Among the truthers. New York: Harper Collins.

Karpowitz, C. F., Quin Monson, J., Patterson, K. D., Pope, J. C. 2011. Tea Time in America? The impact of the Tea Party movement on the 2010 midterm elections. PS: Political Science \& Politics, 44(2).

Madison, J., Hamilton, A., \& Jay, J. 1999. In C. Kesler (Ed.), The Federalist papers. New York: New American Library.

McFarland, A. S. 1987. Interest groups and theories of power in America. British Journal of Political Science, 17, 257-84.

Meyers, M. 1957. The Jacksonian persuasion. New York: Vintage.

Mills, C. W. 1956. The power elite. New York: Oxford University Press.

Nugent, W. 1963. The tolerant Populists: Kansas populism and nativism. Chicago: University of Chicago Press.

Ostler, J. 1992. Why the Populist Party was strong in Kansas and Nebraska but weak in Iowa. The Western Historical Quarterly, 23(4).

Phillips, K. 1993. Boiling point: Republicans, Democrats, and the decline of middle-class prosperity. New York: Random House.

Rasmussen, S., \& Schoen, D. 2010. Mad as hell: How the Tea Party movement is fundamentally remaking our two-party system. New York: Harper.

Schattschneider, E. E. 1975. The semisovereign people: A realists view of democracy in America. New York: Wadsworth.

Schlesinger, A. M., \& Eriksson, E. M. 1924. The vanishing voter. The New Republic, October 15.

Teixeira, R., \& Rogers, J. 2000. America's forgotten majority: Why the white working class still matters. New York: Basic Books.

Tocqueville, A. 2000. In J. P. Mayer (Ed.), Democracy in America. New York: Perennial.

Williamson, V., Skocpol, T., \& Coggin, J. 2011. The Tea Party and the remaking of republican conservatism. Perspective on Politics, March.

Zaller, J. 1992. The nature and origins of mass opinion. Cambridge: Cambridge University Press.

Zachary Courser has taught American Government as a visiting assistant professor at Boston College, Washington \& Lee University, and Claremont McKenna College. He is currently in Lyon, France researching French right-wing politics and editing a book manuscript about how democracy depends on well-developed political parties. This article is based on a paper given as part of a workshop on the future of social conservatism, directed by Jon Shields and sponsored and funded by the Henry Salvatori Center for the Study of Individual Freedom in the Modern World at Claremont McKenna College, May 20-21, 2011. 